\title{
Anthelmintic resistance of Haemonchus contortus from sheep flocks in Brazil: concordance of in vivo and in vitro (RESISTA-Test@) methods
}

\author{
Resistência anti-helmíntica de Haemonchus contortus em rebanhos ovinos no \\ Brasil: concordância de métodos in vivo e in vitro (RESISTA-TestC)
}

\author{
Yousmel Alemán Gainza1; Isabella Barbosa dos Santos'; Amanda Figueiredo"; \\ Leonardo Aparecido Lima dos Santos²; Sérgio Novita Esteves ${ }^{3}$; Waldomiro Barioni-Junior ${ }^{3}$; \\ Alessandro Pelegrine Minho3; Ana Carolina de Souza Chagas ${ }^{3 *}$ (1) \\ ${ }^{1}$ Faculdade de Ciências Agrárias e Veterinárias - FCAV, Universidade Estadual Paulista - UNESP, Jaboticabal, SP, Brasil \\ ${ }^{2}$ Centro Universitário Central Paulista - UNICEP, São Carlos, SP, Brasil \\ ${ }^{3}$ Embrapa Pecuária Sudeste - CPPSE, São Carlos, SP, Brasil
}

\begin{abstract}
How to cite: Gainza YA, Santos IB, Figueiredo A, Santos LAL, Esteves SN, Barioni-Junior W, et al. Anthelmintic resistance of Haemonchus contortus from sheep flocks in Brazil: concordance of in vivo and in vitro (RESISTA-TestC) methods. Braz J Vet Parasitol 2021; 30(2): e025120. https://doi.org/10.1590/S1984-296120201093
\end{abstract}

\begin{abstract}
This study evaluated the resistance status of Haemonchus contortus from sheep flocks in the state of São Paulo, Brazil, through comparison between the fecal egg count reduction test (FECRT) and the larval development test (LDT). For the FECRT, 35 sheep were selected in each of five flocks and divided into groups treated with: benzimidazole, levamisole, ivermectin, monepantel and control. Feces were collected for EPG and fecal cultures. The LDT was performed using thiabendazole (TBZ), levamisole (LEV), ivermectin aglycone (IVM-A) and Zolvix (ZLV). Resistance to all drugs was detected using FECRT in 100\% of the flocks, except in relation to ZLV (40\% resistant and $20 \%$ suspected of resistance). LDT indicated resistance to TBZ and IVM-A in all flocks, to LEV in $80 \%$ of flocks and to ZLV in 10\%. Total agreement was obtained between the two tests for TBZ and IVM $(k=1.0)$, while for LEV $(k=0.8)$ and $Z L V(k=0.9)$, substantial and almost perfect agreement were obtained, respectively. The concordance between the tests was significant, thus showing that it is possible to use the outcome of the LDT to predict the FECRT, and hence validating the former as a fast diagnostic test for use by sheep farmers in Brazil.
\end{abstract}

Keywords: Anthelmintic resistance, FECRT, laboratory diagnosis, RESISTA-Test@, small ruminants.

\begin{abstract}
Resumo
Este estudo avaliou o status de resistência de Haemonchus contortus em rebanhos ovinos do estado de São Paulo, Brasil, através de um estudo comparativo entre o teste de redução da contagem de ovos nas fezes (TRCOF) e o teste de desenvolvimento larvar (TDL). Para o TRCOF, 35 ovinos foram selecionados em cada um dos cinco rebanhos e divididos em grupos tratados com: benzimidazol, levamisol, ivermectina, monepantel e controle. Fezes foram coletadas para OPG e coproculturas. O TDL foi realizado com tiabendazol-TBZ, levamisol-LEV, ivermectina agliconaIVM-A e Zolvix-ZLV. Resistência a todos os fármacos foi detectada por meio do TRCOF em $100 \%$ dos rebanhos, exceto para ZLV (40\% resistentes e $20 \%$ suspeitos de resistência). O LDT indicou resistência ao TBZ e IVM-A em todos os rebanhos; em $80 \%$ dos rebanhos ao LEV e $10 \%$ ao ZLV. Foi obtida concordância total entre os dois testes para TBZ e IVM $(k=1,0)$, enquanto para LEV $(k=0,8)$ e ZLV $(k=0,9)$ foram obtidas concordância substancial e quase perfeita, respectivamente. A concordância entre os testes foi significante, sendo possível usar o resultado do LDT para prever o do TRCOF, validando-se o primeiro como um teste diagnóstico rápido para criadores de ovinos no Brasil.
\end{abstract}

Palavras-chave: Resistência anti-helmíntica, TRCOF, diagnóstico laboratorial, RESISTA- Test $\odot$, pequenos ruminantes.

Received November 3, 2020. Accepted December 10, 2020

*Corresponding author: Ana Carolina de Souza Chagas. E-mail: carolina.chagas@embrapa.br 


\section{Introduction}

Helminthiasis in small ruminants is aggravated by high levels of parasite resistance. This is the current scenario in almost all countries in the world in which sheep farming is present (Kaplan \& Vidyashankar, 2012). The increasing occurrence of gastrointestinal nematodes (GIN) that are resistant to anthelmintics, and the need for reliable information about their establishment and dissemination, indicates that standardized laboratory tests are required (Von Samson-Himmelstjerna et al., 2009; Traversa \& Von Samson-Himmelstjerna, 2016).

Many advances in investigating resistance have been achieved over the past 50 years, including in relation to diagnostics, important physiological and genetic discoveries and the development of predictive mathematical models and tools to help farmers to manage resistance (Kotze et al., 2014). However, this challenge has only been partially overcome. One key issue that still needs to be resolved is to develop faster and easier diagnostic techniques for estimating the presence of anthelmintic resistance that can be used by farmers.

Among the in vivo techniques for detecting resistance, the fecal egg count reduction test (FECRT) stands out. This test is based on comparison of the infection levels estimated through the mean pre-treatment and post-treatment fecal egg counts (FEC) and it needs to meet the recommendations made by Coles et al. (1992). However, FECRT presents some limitations, in that it can underestimate the occurrence of anthelmintic resistance when pretreatment FEC is low. To avoid biases, arithmetic means may be used for the efficacy calculations, or diagnostic methods with low detection limits, e.g., FLOTAC or mini-FLOTAC, can be employed (Traversa \& Von Samson-Himmelstjerna, 2016; George et al., 2017; Wang et al., 2017). In addition, there are flaws in the detection of resistance using FECRT, especially in relation to species with low egg production, such as Teladorsagia circumcincta or Trichostrongylus spp. (Palcy et al., 2010). There have been reports of false positive results in relation to $H$. contortus, $T$. colubriformis and T. circumcincta for levamisole (Cawthorne \& Cheong, 1984; Grimshaw et al., 1994) and false negative results for ivermectin (Jackson, 1993). Moreover, FECRT is considered to be a laborious, time-consuming and expensive test (US\$ 392.95 for a test with six chemical groups and a control group) (Love \& Hutchinson, 2003; DPI, 2012; Chagas et al., 2013; Babják et al., 2018).

Therefore, in vitro assays have been developed to assess parasite resistance to different classes of anthelmintic. The larval development test (LDT) (Hubert \& Kerboeuf, 1992) is considered to be sensitive and practical, and it allows in vitro evaluation of the efficacy of more than one chemical group at the same time, while not depending on embryonated eggs (Kaplan et al., 2007). LDT results have been shown to provide reliable dose-response curves for benzimidazoles (BZs), levamisole (LEV) and ivermectin (IVM) (Taylor, 1990), and reference parasite strains may be included to give a measurement of inter-assay variation (Craven et al., 1999).

In seeking to deal with advancing resistance, the use of sensitive tests to determine the degree of efficacy of a given drug in a specific population of parasites can help in planning control strategies (Taylor et al., 2002). However, even though diagnosing parasitic resistance is of fundamental importance, it is not yet a practical reality in Brazil. Thus, validation of practical methods for making diagnoses through laboratory tests is extremely important. In vitro analyses are less costly and relatively easy to do, and they are able to provide reproducible parameters for measurement of drug resistance, thereby enabling diagnoses that are less dependent on animal experiments (Chagas et al., 2013).

Therefore, the objective of this study was to evaluate the resistance status of $H$. contortus from sheep flocks regarding the chemical groups of benzimidazoles, imidothiazoles, avermectins and amino-acetonitrile derivatives (AADs), through a comparative study between FECRT and LDT.

\section{Material and Methods}

This was an experimental study with a field trial design, in which the research population (animals) was divided into treatment and control groups. Farms were selected on the basis that they had adequate handling facilities and were related to suspected anthelmintic resistance. All data, collected between November 1, 2018 to March 30, 2020, were stored in the computer of the Veterinary Parasitology Laboratory and were backed up monthly in the system of the Embrapa Pecuária Sudeste Data Center.

\section{Sampling procedures for FECRT}

This trial was carried out in the state of São Paulo, Brazil, in five flocks of sheep kept on pasture. To be included in the study, the flocks needed to: (1) have a minimum of 49 animals with FEC $\geq 200$; and (2) have been kept 
without any anthelmintic treatment for at least 12 weeks before the study (Coles et al., 1992). In total, 245 animals of different breeds participated in the experiment, which followed the methodology of Coles et al. (2006). The breed composition of the animals was as follows: crosses of $1 / 2$ Texel and $1 / 2$ Santa Inês (0.82\%); $1 / 2$ île-de-France and $1 / 2$ Santa Inês (1.22\%); $1 / 2$ Dorper and $1 / 2$ Santa Inês (24.08\%); 3/4 Dorper (24.08\%); and other breeds such as Dorper (0.41\%), Texel (2.86\%), White Dorper (3.27\%), Île-de-France (6.12\%), Santa Inês (17.14\%) and Morada Nova (20.00\%).

In each of the five flocks, 35 sheep were divided into five groups $(n=7)$ : untreated control $(C)$, benzimidazole (BZ) (Valbazen 10 oral Cobalt, Pfizer, 5 mg/kg BW), levamisole (LEV) (Ripercol L 150 F injectable, Fort Dodge, $6.2 \mathrm{mg} / \mathrm{kg} \mathrm{BW}$ ), ivermectin (IVM) (Ivomec 1\% injectable, Merial, $0.2 \mathrm{mg} / \mathrm{kg} \mathrm{BW),} \mathrm{and} \mathrm{Zolvix} \mathrm{(ZLV)} \mathrm{(Monepantel} \mathrm{2.5 \%}$ oral, Elanco, $2.5 \mathrm{mg} / \mathrm{kg} \mathrm{BW}$ ).

To form the groups, the flocks were visited one day before the treatment (D-1) to collect feces for individual FEC and for fecal cultures (pooled), to determine which parasite genera were present (Van Wyk et al., 2004). Each group was then allocated seven animals in decreasing order of FEC $(\geq 200)$, in order to obtain a similar average per group. The animals were then weighed and dewormed (D0), in accordance with the specifications of the anthelmintic manufacturer. After 14 days (D14), a third visit to the flocks was made for new collection of feces for individual FEC and fecal cultures (group analysis).

\section{Sampling procedures for LDT}

Feces were collected individually for FECRT on D0 and D14, placed in vacuum-sealable plastic bags (Vac Freezer; Sanremo Sr375), identified and immediately taken to the laboratory for LDT. Egg recovery was performed through sequential use of sieves, following the methodology of Coles et al. (1992). About 70 nematode eggs were added to each well of 96-well plates, along with a nutritive medium as described by Hubert \& Kerboeuf (1992). The plates were identified, sealed with PVC film and kept in an incubator for 24 hours $\left(27^{\circ} \mathrm{C} ; \mathrm{RH} \geq 80 \%\right)$, for the larvae $\left(\mathrm{L}_{1}\right)$ to develop.

After this period, each well received serial dilutions of thiabendazole (TBZ) (Sigma-Aldrich T8904), levamisole (LEV) (Sigma-Aldrich 31742), ivermectin aglycone (IVM-A) (Bioaustralis BIA-I1151) and Zolvix ${ }^{\circledR}$. The stock solutions were prepared by dissolving drugs in dimethyl sulfoxide plus distilled water (maximum DMSO concentration in the well of $0.025 \%$, with subsequent serial dilution, without interference in the larval development). Comparative studies with monepantel (MPT) (chemical base, GS P11144) and Zolvix ${ }^{\circledR}$ (commercial product) had previously indicated that the use of Zolvix ${ }^{\circledR}$ is recommended rather than MPT (Raza et al., 2016; Kotze et al., 2018; Gainza et al., 2020). The negative control consisted of distilled water and nutritive medium. The plates were then incubated again under the same conditions for a further six days. All concentrations of anthelmintic and the negative control were tested as two replicates.

After incubation, eggs and larvae $\left(L_{1}, L_{2}\right.$ and $\left.L_{3}\right)$ from each well were quantified using an inverted microscope and were identified at the genus level (Van Wyk et al., 2004). The numbers of $L_{3}$ Vs. eggs $+L_{1}+L_{2}$ in each well containing the treatments were compared with the control wells to determine the critical well. This was defined as the well in which development to the $L_{3}$ stage was inhibited by $50 \%$, compared with the control wells. Critical wells correspond closely to calculated values for $\mathrm{LC}_{50}$ (Kaplan et al., 2007) and can be used in a similar way to make inferences about the resistance status of the parasite population for a given flock.

\section{FECRT and LDT analyses and resistance determination}

The efficacy of the anthelmintics in the FECRT was estimated using the RESO 4.0 software to define the resistance or susceptibility status of the treated groups in relation to the control group. Resistance was defined as present if (i) the percentage reduction in egg count was less than 95\%; and (ii) the 95\% confidence level was less than $90 \%$. If only one of the two criteria was met, resistance was suspected (Coles et al., 1992; 2006).

In LDT, all larvae in the control wells, and in the wells above and below the critical well, were counted and identified to determine the predominant genus. Resistance of $H$. contortus to anthelmintics was deemed to be present when the predominant parasite $\left(L_{3}\right)$ in the control and critical wells of the plates was of this genus (Australia, 1996).

LC results for susceptible and resistant $H$. contortus isolates were previously determined by Gainza et al. (2020). Comparisons of these values were used to ascertain the anthelmintic resistance status of each flock. It was deemed that, for $H$. contortus: 1 ) the critical wells associated with $L_{50}$ values corresponded to FECRT $\geq 95 \%$ and were classified as susceptible; 2 ) wells associated with delineating doses $\left(\mathrm{LC}_{90}-\mathrm{LC}_{95}\right)$ corresponded to FECRT between 
$80 \%$ to $94 \%$ and were classified as presenting suspected resistance; and 3 ) wells associated with the discriminatory dose value ( $\mathrm{LC}_{99}$ ) corresponded to FECRT $\leq 79 \%$ and were classified as resistant (adapted from Crook et al., 2016).

A value equivalent to a half-well ( 0.5 critical well) was also added to the value of the critical well that was used as a cutoff value, except for ZLV. Thus, the resistance status estimates were conservative so as not to overestimate resistance status. In this manner, results at the limit of resistance would be classified as presenting suspected resistance. The present method developed with these criteria was therefore named the RESISTA-Test@

\section{Statistical analysis}

The degree of concordance between the efficacy (i.e. the parasite was susceptible, suspected of resistance or resistant) found for each chemical group in the FECRT and the critical well obtained in the LDT (where there was $50 \%$ inhibition of larval development $+95 \% \mathrm{Cl}$ ) was ascertained. Then, it was also found an association with the concentration of the drug that was in that critical well (Crook et al., 2016). The Fisher's Exact Chi-square test was used to compare the resistance status of $H$. contortus regarding each chemical group in each flock, and to analyze the level of agreement between the in vivo field test (FECRT) and the in vitro laboratory test (LDT), in order to validate the RESISTA-Test $\odot$. Paired $t$ tests were used to compare the values of the critical wells that were associated with the $\mathrm{LC}_{50}$ and $\mathrm{LC}_{99}$, respectively, for the four chemical groups. It was adopted the following scale to describe the quality of agreement in terms of kappa values: <0: no agreement, 0-0.2: low, 0.2-0.4: fair, 0.4-0.6: moderate, 0.6-0.8: substantial, and 0.8-1: almost perfect (Landis \& Koch, 1977). All the analyses were performed using the XLSTAT Premium 2020.1.1 software (Addinsoft 2020; XLSTAT statistical and data analysis solution; Boston, USA). All effects were evaluated at a 5\% significance level.

\section{Results}

The anthelmintic resistance status of $H$. contortus was determined when this was the predominant genus, as counted in the control and critical wells of the plates. This criterion was met in all the flocks evaluated. The fecal cultures carried out in the control groups on days 0 and 14 can be seen in Figure 1.

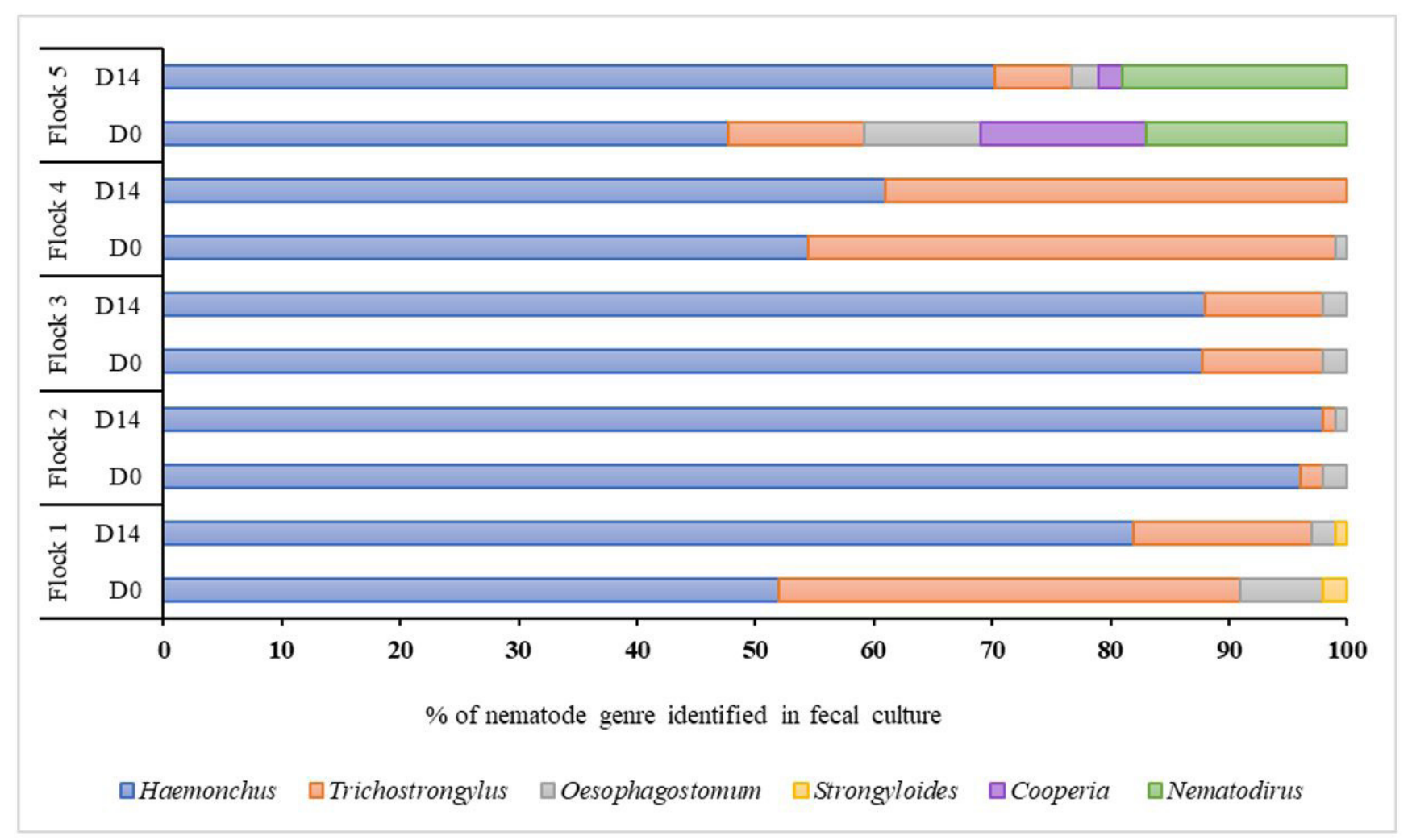

Figure 1. Percentage of nematode genre in fecal culture of the control groups from flocks (Flock 1 to Flock 5) on days 0 and 14. 
Table 1 summarizes the FECRT results for each experimental group in each of the sheep flocks evaluated. Among the five flocks, three (60\%) showed resistance to all anthelmintics (flocks 1, 2 and 4), while two flocks (40\%) showed susceptibility to ZLV (flocks 3 and 5). Flock 4 demonstrated the worst resistance scenario for BZ, LEV and IVM. Although ZLV presented $97 \%$ efficacy, the 95\% confidence level was from 87 to $100 \%$, thus classifying it as giving rise to suspected resistance. In Flock 1, efficacy higher than $80 \%$ was detected for LEV and ZLV.

Table 1. The arithmetic means of fecal egg counts on day 14 after treatment (FEC D14), fecal egg count reduction percentages $(\mathrm{R} \%)$ and the lower and upper $95 \%$ confidence intervals $(\mathrm{Cl})$, in sheep flocks $(\mathrm{N}=49 ; 7$ animals per group) that were tested using the following anthelmintics (AH): benzimidazole (BZ), levamisole (LEV), ivermectin (IVM) and Zolvix (ZLV), and also using an untreated control group (C).

\begin{tabular}{|c|c|c|c|c|c|c|c|c|c|c|}
\hline \multirow{2}{*}{$\mathrm{AH}$} & \multicolumn{2}{|c|}{ Flock 1} & \multicolumn{2}{|c|}{ Flock 2} & \multicolumn{2}{|c|}{ Flock 3} & \multicolumn{3}{|c|}{ Flock 4} & \multirow{2}{*}{$\begin{array}{l}\text { Flock } 5 \\
\text { R\% (CI) }\end{array}$} \\
\hline & FEC D14 & R\% (CI) & FEC D14 & $\mathrm{R} \%(\mathrm{CI})$ & FEC D14 & R\% (CI) & FEC D14 & R\% (CI) & FEC D14 & \\
\hline BZ & 8579 & $0(0-74)$ & 871 & $54(10-76)$ & 2450 & $32(0-79)$ & 836 & $0(0-63)$ & 1667 & $2(0-72)$ \\
\hline LEV & 900 & 89 (79-94) & 350 & $81(44-94)$ & 2471 & $31(0-70)$ & 529 & $37(0-74)$ & 825 & $51(0-85)$ \\
\hline IVM & 11264 & $0(0-66)$ & 1050 & $44(0-81)$ & 3171 & $11(0-69)$ & 2893 & $0(0-0)$ & 1400 & $18(0-71)$ \\
\hline ZLV & 1086 & $87(50-96)$ & 721 & $62(0-90)$ & 71 & 98 (93-99) & 2143 & $97(87-100)$ & 43 & 97 (94-99) \\
\hline C & 8157 & & 1886 & & 3579 & & 836 & & 1700 & \\
\hline
\end{tabular}

*Resistance is present if (i) the percentage reduction in egg count is less than $95 \%$ and (ii) the $95 \%$ confidence level is less than $90 \%$. If only one of the two criteria is met, resistance is suspected (Coles et al., 1992). Bold indicates that the anthelmintic was effective.

In the LDT, the resistance of $H$. contortus to each chemical group in each flock was confirmed based on the concentration in the critical well $\left(\mathrm{LC}_{50}\right)$ and the discriminant concentration $\left(\mathrm{LC}_{99}\right)$. H. contortus in all flocks was classified as resistant to TBZ and, comparing the average concentrations in the critical wells, statistical difference was detected $(P=0.028)$. For $L E V, H$. contortus in all flocks except Flock 2 was considered resistant, with no significant differences among the mean concentrations of critical wells $(P=0.077)$, between the farms. H. contortus in all flocks was resistant to IVM-A, with significant differences between the averages of the critical wells $(P=0.009)$. Lastly, ZLV resistance was detected only in Flock 2, Flock 1 was classified as suspected of resistance, while susceptibility occurred in Flocks 3, 4 and 5, with no differences between the averages $(P=0.096)$.

In comparing the results from LDT and FECRT, there was total agreement between the tests $(\mathrm{k}=1.00)$ regarding the resistance of $H$. contortus to benzimidazoles and TBZ, in all flocks, with no significant differences $(P=0.655)$ (Table 2). LDT showed susceptibility to LEV in Flock 2, while FECRT demonstrated resistance. The critical cutoff point for LEV resistance was $0.001 \mu \mathrm{g} / \mathrm{mL}$. Flock 2 showed critical values below this point, while Flocks 1, 3, 4 and 5 showed values above it, thus indicating resistance to LEV (wells 7.5, 9.5 and 6.5 respectively). However, the chisquare analysis revealed that there was no significant difference between the results obtained from FECRT and LDT for LEV $(P=0.151)$, and substantial agreement between the tests was detected $(k=0.8)$. In the case of IVM-A, there was total agreement $(k=1.0)$ between the tests regarding detection of $H$. contortus resistance in all flocks, with no significant differences ( $P=0.666$ ). Lastly, for ZLV, the critical cutoff point for resistance in the LDT was 0.005 $\mu \mathrm{g} / \mathrm{mL}$. Flock 2 presented values above this point (well 9.5) and Flocks 3 and 5 had values below it, thus indicating susceptibility, and these showed total agreement with the results from the FECRT $(k=1.0)$. Also, ZLV results from Flocks 1 and 4 showed substantial agreement with those of FECRT $(k=0.8)$. The chi-square analysis revealed that there was no significant difference $(P=0.116)$ between the results obtained from FECRT and LDT for ZLV, which presented almost perfect agreement $(\mathrm{k}=0.9)$.

\section{Discussion}

This was the first study carried out in Brazil comparing FECRT and LDT to detect the resistance of GIN to four chemical groups in small ruminants. These chemical groups used in LDT were selected based on previous research that had demonstrated a dose-response relationship with regard to detecting resistance to anthelmintics in vitro (Coles et al., 1992; 2006). In the present study, LDT revealed that $H$. contortus presented resistance to TBZ (100\% of the flocks), IVM-A (100\%), LEV (60\%) and ZLV (20\%). In FECRT, resistance to the anthelmintics evaluated was detected in $60 \%$ of the flocks, for all drugs except ZLV, to which $40 \%$ were susceptible. These results were expected, 
Diagnosis of anthelmintic resistance in sheep

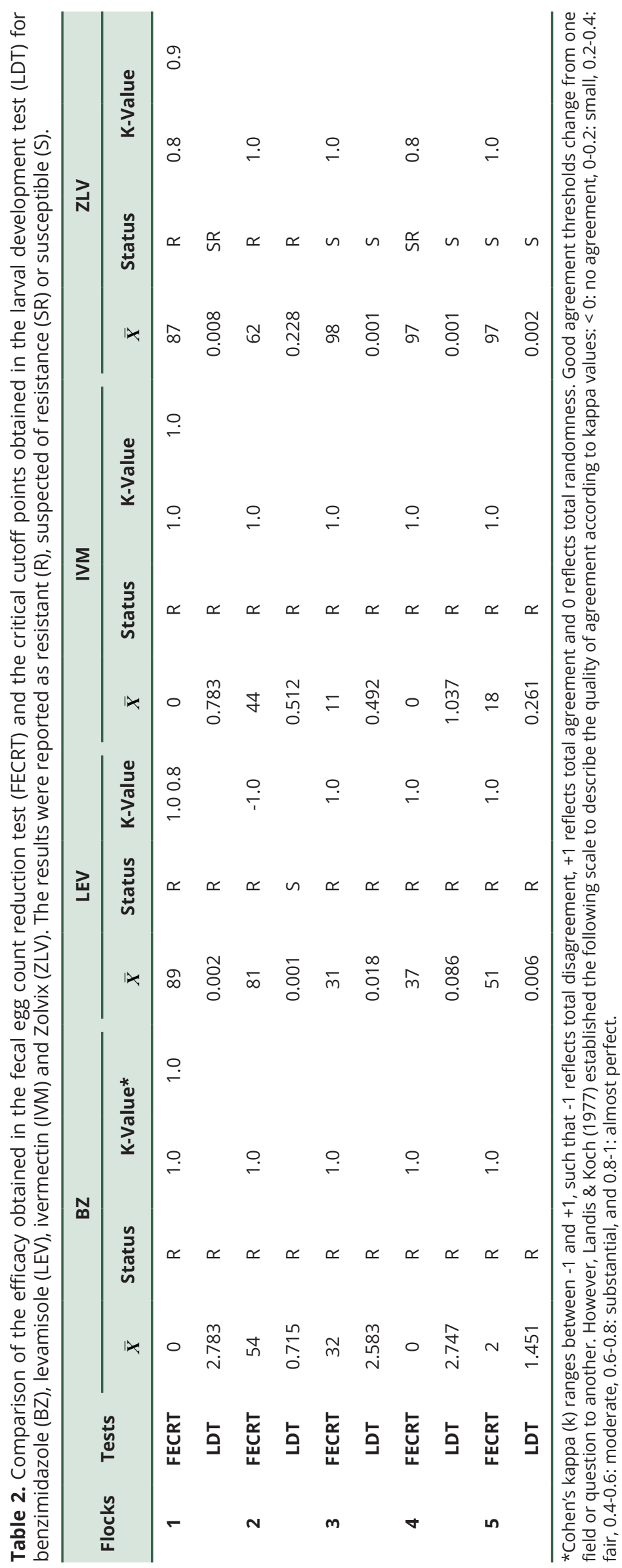


since Salgado et al. (2019) had reported that multiple anthelmintic resistance is a serious problem within sheep production in Brazil.

In order to set up a comparison between in vitro and in vivo tests, the discriminatory doses for detection of resistance in LDT were established for all anthelmintics. The critical cutoff points $\left(L C_{50}\right)$ for resistance were:

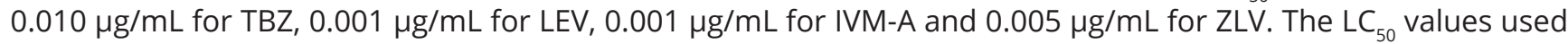
as cutoff values or discriminatory doses for detecting resistance were determined. Discriminant doses were also determined in other studies for use in LDT: $0.1 \mu \mathrm{g} / \mathrm{mL}$ for TBZ and $1 \mu \mathrm{g} / \mathrm{mL}$ for LEV, against $H$. contortus (Hong et al., 1996; Mitchell et al., 2010); $0.02 \mu \mathrm{g} / \mathrm{mL}$ for TBZ and $0.5 \mu \mathrm{g} / \mathrm{mL}$ for LEV against $H$. contortus, $T$. circumcincta and T. colubriformis (Coles et al., 2006); and $0.01 \mu \mathrm{g} / \mathrm{mL}$ for TBZ, $2.5 \mu \mathrm{g} / \mathrm{mL}$ for LEV and $0.0008 \mu \mathrm{g} / \mathrm{mL}$ for IVM to H. contortus (Taylor, 1990).

It should be noted that our results differed regarding the cutoff values for LEV, from those reported by Taylor (1990), Hong et al. (1996) and Mitchell et al. (2010). However, those authors had used commercial anthelmintics in their assays to perform the LDT and determine the $L_{50}$. Because of this, it is necessary to highlight the importance of using standard substances in order to establish cutoff criteria and reduce the variability of the criteria to a minimum. Although in the present study the approach used to determine the cutoff values $\left(\mathrm{LC}_{50}\right)$ for MPT was through the commercial anthelmintic (Zolvix ${ }^{\circledR}$ ), it was justified by the fact that in previous studies Zolvix ${ }^{\circledR}$ presented better performance than MPT (chemical base), for detecting resistance to LDT among $H$. contortus (Lecová et al., 2013; Raza et al., 2016; Kotze et al., 2018; Gainza et al., 2019).

The present study indicated that a good association existed between FECRT and LDT with regard to detection of $H$. contortus resistant to benzimidazoles and TBZ. Similar findings were reported by Grimshaw et al. (1994) using the FECRT, egg hatch test and LDT on sheep farms in southern England, and by Crook et al. (2016) on sheep and goat farms in the Central Atlantic region of the United States. High frequency of resistance to benzimidazoles (BZs) in the state of São Paulo was previously described by Veríssimo et al. (2012). Anthelmintics from this chemical group have been the basis for GIN control in many countries for decades (Chaudhry et al., 2015; Ali et al., 2019). However, resistance to BZs is an established problem worldwide, in regions where production of small ruminants is essential (Lalljee et al., 2019). Nonetheless, this chemical group is still widely used, which is probably why resistant alleles in sheep flocks continue to be observed at high or increasing frequencies.

Despite the differences in results between FECRT and LDT regarding resistance to LEV and ZLV in some flocks, these were not statistically significant. In these flocks, LDT showed susceptibility to LEV and ZLV, while FECRT showed resistance and suspected resistance. Although LDT assesses resistance to chemical compounds, it is important to highlight that anthelmintics can present some efficacy even when the level of resistance is not very high (period of resistance establishment). This provides an explanation for why, according to the LDT, LEV was more effective in Flock 2 while ZLV was more effective in Flocks 1 and 4 than in the others, which had higher critical resistance values. Previous studies have reported conflicting results only for resistance to LEV, between FECRT and LDT (Maingi et al., 1998). However, the data from the present study indicated that the results from the two tests are comparable. The improvement of the LDT accuracy will continue in the coming years. In this way, adjustments in the interpretation of critical wells and associated drug concentration cutoffs will be possible with more assertiveness from a larger sample of flocks, which will allow reaching total agreement for LEV and ZLV drugs as well.

The anthelmintic resistance for IVM-A among $H$. contortus isolates in the flocks that was detected using LDT was also detected using FECRT. Thus, the agreement between the results was due to use of IVM-A in the LDT. The use of this molecule significantly increases the ability of LDT to differentiate between susceptible and resistant isolates (Dolinská et al., 2013; 2014).

Anthelmintic resistance is an evolutionary process that is impossible to prevent if anthelmintics are used in a flock (Kaplan, 2020), but it is possible to reduce the rate at which resistance develops by modifying strategies of anthelmintic use. For this reason, diagnosing resistance early on is fundamental. In the current work, we took a conservative approach in assigning cutoff points for resistance and included a borderline category (suspected of resistance) in order to avoid classifying flocks as presenting resistance when they are indeed susceptible. The cutoff points for assigning low resistance status presented critical well values that were 1.5 to 2.0 higher than the cutoff point for assigning susceptible status. This corresponded to an increase in the drug concentration. Thus, we believe that flocks with suspected resistance represented an important shift towards resistance. The cutoff points for assigning resistant status presented critical well values $\geq 2.5$ higher than the cutoff point for assigning susceptible status, which corresponded to a fivefold increase in drug concentration. 
FECRT is an important tool for diagnosing resistance, but it can be extremely laborious and expensive for the producer. In addition, this method may sometimes not be an option for small farmers, due to the small number of animals and the minimum number of animals required in order to test for multiple anthelmintic agents. On the other hand, LDT also has limitations, such as contamination of the culture medium, the labor of parasite counting and dependence on purchasing drug molecules. Even so, it clearly has advantages over FECRT. The LDT validated in the present study offers a faster and more reliable laboratory test alternative for resistance monitoring and can be used in sustainable integrated parasite management by Brazilian sheep farmers and technicians.

\section{Conclusion}

The data from the present study indicated that $H$. contortus had a multiple-resistance profile in the flocks evaluated. Total agreement was obtained regarding the results from the two tests for TBZ and IVM-A, and substantial and almost perfect agreement for LEV and ZLV, respectively. The correlations between the tests were usually good and it was possible to use the outcome of LDT to predict the outcome of FECRT, thus validating the former for use by farmers. This test was here named the RESISTA-Test $\odot$ for diagnosing resistance presented by $\mathrm{H}$. contortus, the main parasite of small ruminants in tropical countries.

\section{Acknowledgements}

We thank the Fundação de Amparo à Pesquisa do Estado de São Paulo/FAPESP and Embrapa for their financial support to this study. Scholarships were conceded by FAPESP (grant no. 2014/25821-0, 2016/07132-8, 2017/13249-8 and 2018/16070-1).

\section{References}

Ali Q, Rashid I, Shabbir MZ, Aziz-Ul-Rahman, Shahzad K, Ashraf K, et al. Emergence and the spread of the F200Y benzimidazole resistance mutation in Haemonchus contortus and Haemonchus placei from buffalo and cattle. Vet Parasitol 2019; 265: 48-54. http://dx.doi.org/10.1016/j.vetpar.2018.12.001. PMid:30638520.

Australia. DrenchRite: a larval development assay for the detection of anthelmintic resistance: standard operating procedures. Australia: Horizon Technology Pty Limited; 1996. 34 p.

Babják M, Königová A, Urda Dolinská M, Vadlejch J, Várady M. Anthelmintic resistance in goat herds: in vivo versus in vitro detection methods. Vet Parasito/ 2018; 254: 10-14. http://dx.doi.org/10.1016/j.vetpar.2018.02.036. PMid:29656993.

Cawthorne RJG, Cheong FH. Prevalence of anthelmintic resistant nematodes in sheep in south-east England. Vet Rec 1984; 114(23): 562-564. http://dx.doi.org/10.1136/vr.114.23.562. PMid:6464318.

Chagas ACS, Katiki LM, Silva IC, Giglioti R, Esteves SN, Oliveira MCS, et al. Haemonchus contortus: a multiple-resistant Brazilian isolate and the costs for its characterization and maintenance for research use. Parasitol Int 2013; 62(1): 1-6. http://dx.doi. org/10.1016/j.parint.2012.07.001. PMid:22809891.

Chaudhry U, Redman EM, Raman M, Gilleard JS. Genetic evidence for the spread of a benzimidazole resistance mutation across southern India from a single origin in the parasitic nematode Haemonchus contortus. Int J Parasito/ 2015; 45(11): 721-728. http:// dx.doi.org/10.1016/j.jpara.2015.04.007. PMid:26099649.

Coles GC, Bauer C, Borgsteede FHM, Geerts S, Klei TR, Taylor MA, et al. World Association for the Advancement of Veterinary Parasitology (W.A.A.V.P) methods for the detection of anthelmintic resistance in nematodes of veterinary importance. Vet Parasitol 1992; 44(1-2): 35-44. http://dx.doi.org/10.1016/0304-4017(92)90141-U. PMid:1441190.

Coles GC, Jackson F, Pomroy WE, Prichard RK, Von Samson-Himmelstjerna G, Silvestre A, et al. The detection of anthelmintic resistance in nematodes of veterinary importance. Vet Parasitol 2006; 136(3-4): 167-185. http://dx.doi.org/10.1016/j. vetpar.2005.11.019. PMid:16427201.

Craven J, Bjørn H, Barnes EH, Henriksen SA, Nansen PA. Comparison of in vitro tests and a faecal egg count reduction test in detecting anthelmintic resistance in horse strongyles. Vet Parasitol 1999; 85(1): 49-59. http://dx.doi.org/10.1016/S03044017(99)00113-2. PMid:10447192.

Crook EK, O'Brien DJ, Howell SB, Storey BE, Whitley NC, Burke JM, et al. Prevalence of anthelmintic resistance on sheep and goat farms in the mid-Atlantic region and comparison of in vivo and in vitro detection methods. Small Rumin Res 2016; 143: 89-96. http://dx.doi.org/10.1016/j.smallrumres.2016.09.006. 
Department of Primary Industries - DPI. New South Wales. Laboratory fees for common tests [online]. 2012 [cited 2020 Sept 20]. Available from: http://www.dpi.nsw.gov.au/agriculture/vetmanual/submission/lab-charges

Dolinská M, Ivanišinová O, Königová A, Várady M. Anthelmintic resistance in sheep gastrointestinal nematodes in Slovakia detected by in-vitro methods. BMC Vet Res 2014; 10(1): 233. http://dx.doi.org/10.1186/s12917-014-0233-4. PMid:25270360.

Dolinská M, Königová A, Letková V, Molnár L, Várady M. Detection of ivermectin resistance by a larval development test-back to the past or a step forward? Vet Parasito/ 2013; 198(1-2): 154-158. http://dx.doi.org/10.1016/j.vetpar.2013.07.043. PMid:23993637.

Gainza YA, Fantatto RR, Albuquerque AC, Amarante AFT, Ferraz Júnior RS, Niciura SCM, et al. Padronização do teste de desenvolvimento larvar (TDL) para diagnóstico da resistência anti-helmíntica em Haemonchus contortus [online]. São Carlos: Embrapa Pecuária Sudeste; 2019. 23 p. (Boletim de Pesquisa e Desenvolvimento; no. 44) [cited 2020 Sept 20]. Available from: https:// ainfo.cnptia.embrapa.br/digital/bitstream/item/192168/1/Boletim44.pdf

Gainza YA, Santos IB, Figueiredo A, Amarante AFT, Esteves SN, Barioni-Junior W, et al. Improvement of an in vitro test (RESISTA-Test@) for Haemonchus contortus resistance diagnosis in small ruminant. São Carlos: Embrapa Pecuária Sudeste; 2020.38 p. (Boletim de Pesquisa e Desenvolvimento; no. 48) [cited 2020 Sept 20]. Available from: http://ainfo.cnptia.embrapa.br/digital/bitstream/ item/218503/1/ImprovementVitroTest-BOLETIM-48.pdf

George MM, Paras KL, Howell SB, Kaplan RM. Utilization of composite fecal samples for detection of anthelmintic resistance in gastrointestinal nematodes of cattle. Vet Parasito/2017; 240: 24-29. http://dx.doi.org/10.1016/j.vetpar.2017.04.024. PMid:28576340.

Grimshaw WTR, Hunt KR, Hong C, Coles GC. Detection of anthelmintic resistant nematodes in sheep in southern England by a faecal egg count reduction test. Vet Rec 1994; 135(16): 372-374. http://dx.doi.org/10.1136/vr.135.16.372. PMid:7831741.

Hong C, Hunt KR, Coles GC. Occurrence of anthelmintic resistant nematodes on sheep farms in England and goat farms in England and Wales. Vet Rec 1996; 139(4): 83-86. http://dx.doi.org/10.1136/vr.139.4.83. PMid:8843638.

Hubert J, Kerboeuf D. A microlarval development assay for the detection of anthelmintic resistance in sheep nematodes. Vet Rec 1992; 130(20): 442-446. http://dx.doi.org/10.1136/vr.130.20.442. PMid:1621342.

Jackson F. Anthelmintic resistance: the state of play. Br Vet J 1993; 149(2): 123-138. http://dx.doi.org/10.1016/S0007-1935(05)800831. PMid:8485639.

Kaplan RM, Vidyashankar AN, Howell SB, Neiss JM, Williamson LH, Terrill TH. A novel approach for combining the use of in vitro and in vivo data to measure and detect emerging moxidectin resistance in gastrointestinal nematodes of goats. Int J Parasitol 2007; 37(7): 795-804. http://dx.doi.org/10.1016/j.ijpara.2007.01.001. PMid:17307184.

Kaplan RM, Vidyashankar NA. An inconvenient truth: global worming and anthelmintic resistance. Vet Parasito/ 2012; 186(1-2): 70-78. http://dx.doi.org/10.1016/j.vetpar.2011.11.048. PMid:22154968.

Kaplan RM. Biology, epidemiology, diagnosis, and management of anthelmintic resistance in gastrointestinal nematodes of livestock. Vet Clin North Am Food Anim Pract 2020; 36(1): 17-30. http://dx.doi.org/10.1016/j.cvfa.2019.12.001. PMid:32029182.

Kotze AC, Hunt PW, Skuce P, Von Samson-Himmelstjerna G, Martin RJ, Sager H, et al. Recent advances in candidate-gene and whole-genome approaches to the discovery of anthelmintic resistance markers and the description of drug/receptor interactions. Int J Parasitol Drugs Drug Resist 2014; 4(3): 164-184. http://dx.doi.org/10.1016/j.ijpddr.2014.07.007. PMid:25516826.

Kotze AC, Ruffell A, Lamb J, Elliott TP. Response of drug-susceptible and -resistant Haemonchus contortus larvae to monepantel and abamectin alone or in combination in vitro. Vet Parasitol 2018; 249: 57-62. http://dx.doi.org/10.1016/j.vetpar.2017.11.007. PMid:29279087.

Lalljee SV, Soundararajan C, Singh YD, Sargison ND. The potential of small ruminant farming as a means of poverty alleviation in rural southern India. Trop Anim Health Prod 2019; 51(2): 303-311. http://dx.doi.org/10.1007/s11250-018-1686-4. PMid:30112734.

Landis JR, Koch GG. The measurement of observer agreement for categorical data. Biometrics 1977; 33(1): 159-174. http://dx.doi. org/10.2307/2529310. PMid:843571.

Lecová L, Stuchlíková L, Lamka J, Špulák M, Várady M, Skálová L. Efficacy of monepantel against lower developmental stages of a multi-resistant and susceptible Haemonchus contortus isolates: an in vitro study. Helminthologia 2013; 50(2): 91-95. http:// dx.doi.org/10.2478/s11687-013-0114-6.

Love SCJ, Hutchinson GW. Pathology and diagnosis of internal parasites in ruminants. In: Cook RW, Kelly WR, editors. Gross pathology of ruminants: proceedings 350 [online]. Sydney: Post Graduate Foundation in Veterinary Science, University of Sydney; 2003 [cited 2020 Sept 20]. Available from: https://aapspextranet.animalhealthaustralia.com.au/wp-content/uploads/2019/04/16 Chapter16.pdf

Maingi N, Bjorn H, Dangolla A. The relationship between faecal egg count reduction test and the lethal dose $50 \%$ in the egg hatch assay and larval development assay. Vet Parasito/ 1998; 77(2-3): 133-145. http://dx.doi.org/10.1016/S0304-4017(97)002227. PMid:9746283. 
Mitchell ESE, Hunt KR, Wood R, McLean B. Anthelmintic resistance on sheep farms in Wales. Vet Rec 2010; $166(21)$ : 650-652. http://dx.doi.org/10.1136/vr.b4840. PMid:20495166.

Palcy C, Silvestre A, Sauve C, Cortet J, Cabaret J. Benzimidazole resistance in Trichostrongylus axei in sheep: long-term monitoring of affected sheep and genotypic evaluation of the parasite. Vet J 2010; 183(1): 68-74. http://dx.doi.org/10.1016/j.tvjl.2008.09.012. PMid:18980850.

Raza A, Lamb J, Chambers M, Hunt PW, Kotze AC. Larval development assays reveal the presence of sub-populations showing high- and low-level resistance in a monepantel (Zolvix®) -resistant isolate of Haemonchus contortus. Vet Parasitol 2016; 220: 7782. http://dx.doi.org/10.1016/j.vetpar.2016.02.031. PMid:26995725.

Salgado JA, Cruz LV, Rocha LOD, Sotomaior CS, Borges TD, Santos CP. Implication of the fecal egg count reduction test (FECRT) in sheep for better use of available drugs. Rev Bras Parasitol Vet 2019; 28(4): 700-707. http://dx.doi.org/10.1590/s1984-29612019093. PMid:31800888.

Taylor MA, Hunt KR, Goodyear KL. Anthelmintic resistance detection methods. Vet Parasito/ 2002; 103(3): 183-194. http://dx.doi. org/10.1016/S0304-4017(01)00604-5. PMid:11750111.

Taylor MA. A larval development test for the detection of anthelmintic resistance in nematodes of sheep. Res Vet Sci 1990; 49(2): 198-202. http://dx.doi.org/10.1016/S0034-5288(18)31077-4. PMid:2236917.

Traversa D, Von Samson-Himmelstjerna G. Anthelmintic resistance in sheep gastro-intestinal strongyles in Europe. Small Rumin Res 2016; 135: 75-80. http://dx.doi.org/10.1016/j.smallrumres.2015.12.014.

Van Wyk JA, Cabaret J, Michael LM. Morphological identification of nematode larvae of small ruminants and cattle simplified. Vet Parasitol 2004; 119(4): 277-306. http://dx.doi.org/10.1016/j.vetpar.2003.11.012. PMid:15154594

Veríssimo CJ, Niciura SC, Alberti AL, Rodrigues CF, Barbosa CM, Chiebao DP, et al. Multidrug and multispecies resistance in sheep flocks from São Paulo state, Brazil. Vet Parasitol 2012; 187(1-2): 209-216. http://dx.doi.org/10.1016/j.vetpar.2012.01.013. PMid:22341829.

Von Samson-Himmelstjerna G, Coles GC, Jackson F, Bauer C, Borgsteede F, Cirak VY, et al. Standardization of the egg hatch test for the detection of benzimidazole resistance in parasitic nematodes. Parasitol Res 2009; 105(3): 825-834. http://dx.doi. org/10.1007/s00436-009-1466-1. PMid:19452165.

Wang C, Torgerson PR, Höglund J, Furrer R. Zero-inflated hierarchical models for faecal egg counts to assess anthelmintic efficacy. Vet Parasitol 2017; 235: 20-28. http://dx.doi.org/10.1016/j.vetpar.2016.12.007. PMid:28215863. 